\title{
Response of Strawberry to Salicylic Acid and Yeast Extract Applications under Different Nitrogen and Potassium Combinations
}

\author{
Abo-Sedera*, F.A.; L.A. Badr*; Amany A. Abd- Elatif** and S.M. Rezk** \\ *Hort. Dept., Fac. of Agric., Moshtohor, Benha University. \\ **Potato and Vegetatively Propagated Crops Dept., Hort. Res. Institute, ARC.
}

\begin{abstract}
This study was conducted during the two successive seasons of 2011/2012 and 2012/2013 in a private farm at El-Dair village, Kalubia governorate, to investigate the response of strawberry to salicylic acid and yeast extract applications under different nitrogen and potassium fertilizers combinations. Data were recorded on vegetative growth, chemical constituents, yield and its components as well as fruit quality.

Results indicate that application of mineral fertilizers at the highest used levels $(150 \mathrm{~kg} \mathrm{~N}+200 \mathrm{~kg}$ $\mathrm{K}_{2} \mathrm{O}$ or $200 \mathrm{~kg} \mathrm{~N}+300 \mathrm{~kg} \mathrm{~K}_{2} \mathrm{O}$ ) per fed. combined with spraying the plants with salicylic acid at $1 \mathrm{~g} / \mathrm{L}$ or yeast extract $100 \mathrm{ml} / \mathrm{L}$ exhibited the highest values in the measured growth parameters i.e., plant height, number of leaves and crowns per plant, crown diameter, average leaf area as well as fresh and dry weight per plant during both seasons. Also, the same treatments gave the highest values of phosphorus, potassium and total carbohydrates during both seasons of study. Results also show that using the highest rate of $\mathrm{N}$ and $\mathrm{K}$ fertilizers (200 kg N+ $300 \mathrm{~kg} \mathrm{~K} \mathrm{~K}_{2} \mathrm{O}$ ) and spraying the plants with salicylic acid (1g / liter) reflected the highest produced yield and its components. Moreover, it reflected also the highest values of all determined physical and chemical fruit quality characters (average fruit length, diameter, weight and fruit firmness, TSS, Vitamin C, acidity, total sugars and anthocyanin) during both seasons. The study recommend adding $200 \mathrm{Kg} \mathrm{N}+300 \mathrm{~kg} \mathrm{~K}_{2} \mathrm{O}$ per fed and spraying the plants with salicylic acid at $1 \mathrm{~g} / \mathrm{L}$ to enhance plant growth and increase yield and its components particularly early and exportable yield as well as physical and chemical fruit characteristics, under Kalubia governorate conditions.
\end{abstract}

Keywords: Strawberry, salicylic acid, yeast extract, N, K fertilization, yield, fruit quality.

\section{Introduction}

Concerning the effect of NPK fertilizers on plant vegetative growth traits, Abd El-Aziz (2007) indicated that potassium fertilization had insignificant effect on plant growth characteristics except plant length. Abo Sedera et al. (2009) found that, using mineral $-\mathrm{N}$ fertilizer alone or along with compost at the recommended dose $(200 \mathrm{~kg} \mathrm{~N} / \mathrm{fed}$.) had better effect on the studied vegetative growth traits. Mosalem (2010) on strawberry indicated that application of mineral fertilizers at $125 \%$ of the recommended dose $\left(250 \mathrm{~kg} \mathrm{~N}+100 \mathrm{~kg} \mathrm{P}_{2} \mathrm{O}_{5}+300 \mathrm{~kg}\right.$ $\mathrm{K}_{2} \mathrm{O}$ ) reflected the highest plant height, number of leaves and secondary crowns /plant, leaf area, crown diameter, fresh and dry weight per plant. Mohamed (2008), Shafshak et al. 2010 and Jamali et al. (2013) found that spraying plants with natural anti disease substances i.e. salicylic acid increased plant height, number of leaves and crowns per plant, fresh and dry weight per plant as well as leaf area, Saleh (2004) on strawberry showed that spraying plants with $25 \mathrm{ml} / \mathrm{l}$ yeast extract plus mixture of micronutrients significantly increased number of leaves, number of crowns, fresh weight and dry weight per plant. On the other hand, Ahmed (2011) on strawberry found that foliar application of yeast extract at rate of $2.5 \%$ did not reflect any significant effects on all studied growth aspects except number of leaves. Kaponski and Kaweeki (1994) on strawberry reported that using $90 \mathrm{~kg} \mathrm{~N}$ and $160 \mathrm{~kg}$ $\mathrm{K}_{2} \mathrm{O}$ / ha increased leaf $\mathrm{K}$ and $\mathrm{P}$ contents. Abd ElAziz (2007) on strawberry reported that there were significant increments in potassium and carbohydrates content of plant with increasing potassium fertilizer units from 250 up to 500units $\mathrm{K}_{2} \mathrm{O} /$ fed. In addition, non significant effect on nitrogen and phosphorus content in foliage was noticed. Mosalem (2010) on strawberry reported that application of mineral fertilizers at $125 \%$ of the recommended dose $\left(250 \mathrm{~kg} \mathrm{~N}+100 \mathrm{~kg} \mathrm{P}_{2} \mathrm{O}_{5}+300 \mathrm{~kg}\right.$ $\mathrm{K}_{2} \mathrm{O} /$ fed) reflected the highest values of total nitrogen, phosphorus, potassium and total carbohydrates content in plant foliage. Karlidag et al (2009) found that the greatest values of almost contents of all nutrients of leaves were obtained with $1.00 \mathrm{mM}$ salicylic acid treatments in both saline and non-saline conditions. Jamali et al. (2013) on strawberry found that foliar spray with salicylic acid at rates of 1,2 , and $3 \mathrm{mM}$ significantly increased nitrogen concentration within leaves. Abd El-All (2009) on tomato illustrated that spraying yeast extract significantly increased $\mathrm{N}, \mathrm{P}$, $\mathrm{K}$, $\mathrm{Ca}$ and $\mathrm{Mg}$ concentrations of treated plants compared with the control treatment. Ali (2010) on common bean found that spraying plants with dry yeast at rates of 2 and $4 \mathrm{~g} / \mathrm{l}$ after 20,30 and 40 days from sowing significantly increased all macroelements content compared with the control treatment. EL-Shal et al. (2003), found that increasing NPK rate was accompanied with 
significant increases in yield potentials (early yield/plant, non-marketable yield and total yield/plant.

Mosalem (2010) reported that application of mineral fertilizers (NPK) at $125 \%$ of the recommended dose $\left(250 \mathrm{~kg} \mathrm{~N}+100 \mathrm{~kg} \mathrm{P}_{2} \mathrm{O}_{5}+300 \mathrm{~kg}\right.$ $\mathrm{K}_{2} \mathrm{O} / \mathrm{fed}$ ) resulted in the highest total fruit yield and its components expressed as early, exportable and marketable strawberry yield per feddan. In addition, no significant differences were noticed in total yield and its components in case of using mineral fertilizers at $100 \%$. Shafshak et al. (2010) showed that spraying strawberry plants with salicylic acid at $5 \mathrm{mM}$ positively increased early, total and marketable fruit yield. El Sayed (2010) on strawberry reported that different NPK levels increased fruit length, weight and firmness. However, it increased ascorbic acid, anthocyanin and TSS. Abd El-Aziz (2007) indicted that application of K-fertilizer had no significant effect on physical characters of strawberry fruits. Mosalem(2010)on strawberry indicated that fertilizing the plants with mineral fertilizes (NPK) at $125 \%$ of the recommended dose significantly increased all the studied physical fruit parameters, i.e., average fruit length, diameter and weight except fruit firmness which was not significantly affected. Saleh (2004) reported that spraying the strawberry plants with yeast extract increased vitamin $\mathrm{C}$ concentration.

Therefore, this study was conducted to investigated the response of strawberry to salicylic acid and yeast extract applications under different nitrogen and potassium combinations,

\section{Materials and Methods}

Two field experiments were carried out during the two successive seasons of 2011/2012 and $2012 / 2013$ in a private farm at El-Dair village, Kalubia governorate, to investigate the response of strawberry to salicylic acid and yeast extract applications under different nitrogen and potassium combinations,

Table a. Mechanical and chemical analyses of the used soil.

\begin{tabular}{|c|c|c|c|c|c|}
\hline Physical analysis & & $\begin{array}{l}\text { Chemical ana } \\
\text { Cations meq/l }\end{array}$ & & Anions & \\
\hline Coarse sand & $17.3 \%$ & $\mathrm{Ca}^{++}$ & 2.4 & $\mathrm{CO}_{3}^{--}$ & Zero \\
\hline Fine sand & $35.4 \%$ & $\mathrm{Mg}^{++}$ & 1.0 & $\mathrm{HCO}_{3}^{-}$ & 3.5 \\
\hline Silt & $29.2 \%$ & $\mathrm{Na}^{+}$ & 6.0 & $\mathrm{Cl}^{-}$ & 7.4 \\
\hline Clay & $18.7 \%$ & $\mathrm{~K}^{+}$ & 7.0 & $\mathrm{SO}_{4}^{--}$ & 2.7 \\
\hline Texture class & clay loam & & & & \\
\hline Soil pH & 7.32 & Available $\mathrm{N}$ & & & \\
\hline E.C, $\mathrm{dS} / \mathrm{m}$ & 1.91 & Available P & & & \\
\hline Organic matter & $2.4 \%$ & Available $\mathrm{K}$ & & & \\
\hline
\end{tabular}

The area of the experimental plot was $14 \mathrm{~m}^{2}$ included two beds each four meters in length and 1.20 meters in width. Each bed included four rows and the transplanting was done at $25 \mathrm{~cm}$ apart between transplants in the same row. Transplanting was done on 15 and 12 of September in 2011/2012 and 2012/2013, respectively. Sprinkler irrigation was used in the first month after transplanting, after that the beds were covered with 40 micron black plastic mulch. After planting the drip irrigation was used after mulching until the end of the growing season.

This experiment included 9 treatments resulted from the combination between three levels of $\mathrm{N}, \mathrm{K}$ mineral fertilizer and two spray treatments (antioxidant) in addition to the control treatment on strawberry plants cv. Florida. As follows

a- N, K fertilization treatments.

$1-100 \mathrm{~kg} \mathrm{~N}+100 \mathrm{~kg} \mathrm{~K}_{2} \mathrm{O} . / \mathrm{fed}$

$2-150 \mathrm{~kg} \mathrm{~N}+200 \mathrm{~kg} \mathrm{~K} 2 \mathrm{O} . / \mathrm{fed}$

3- $200 \mathrm{~kg} \mathrm{~N}+300 \mathrm{~kg} \mathrm{~K}_{2} \mathrm{O} /$ fed (control).

\section{b- Spray treatments.}

1- Foliar spray with yeast extract at $100 \mathrm{ml} / \mathrm{l}$

2- Foliar spray with salicylic acid (SA) at $1 \mathrm{~g} / 1$.
3- Foliar spray with distilled water( control). Ammonium nitrate $(33 \% \mathrm{~N})$ and potassium salphate $\left(50 \% \mathrm{~K}_{2} \mathrm{O}\right)$ were used as a source of nitrogen and potassium All treatments received $80 \mathrm{~kg} /$ fed.of $\mathrm{P}_{2} \mathrm{O}_{5}$ phosphorus. The amounts of mineral fertilizers were devided into equal portions and were added thought the irrigation water (fertigation) two times per week starting 21 days after transplanting and ended 15 days before the end of harvesting season. Foliar spray treatments were started after 20 days from transplanting and every 15 days four times throughout the growing season.

\section{Data recorded:}

\section{Vegetative growth characteristics.}

Five plants were taken from each experimental plot as a representative sample on February after130 days from transplanting and the following data were recorded.

1- Plant length, fresh and dry weight per plant, number of crowns/plant, number of leaves/plant, leaf area $\left(\mathrm{cm}^{2}\right)$ and crown diameter

2- Total nitrogen, phosphorus and potassium: were determined in the digested dry matter of plant foliage according to the methods described 
by Kock and Mc Meeckin (1924), Trough and Meyer (1939) and Brown and Lilliland (1946), respectively

3- Total protein: Protein content was calculated by using the conversion factor $(\mathrm{N} \times 6.25)$ as described by Pregl (1945).

4- Total carbohydrates: It was determined colormetrically according to method described by James (1995).

5- Fruit yield and its components:

A. Early fruit yield: It was determined as weight of all harvested fruits at the ripe stage during November, December and January.

B. Total fruit yield: It was calculated using total fruit yield per plot.

C- Fruit yield (per plant): It was calculated from fruit yield/plot and number of plants/plot.

D- Marketable yield: it was calculated after discarding the infected fruits.

E- Un-marketable yield (kg/fed): It was calculated as weight of infected fruits during the harvesting season.

F- Exportable yield (t/fed): it was calculated as weight of harvested fruits at the $3 / 4$ color stage during November, December and January, after discarding the misshaped fruits.

\section{6- Fruit quality}

Physical and chemical fruit quality: A random sample of 10 fruits at marketable stage from each experimental plot was taken to determine the following properties. Average fruit weight, fruit firmness. Total soluble solids (T.S.S.), total titratable acidity, ascorbic acid and anthocyanin as the method described in A. O. A.C. (1990). Total sugars were detrimined as the method described by Nelson (1974). Nitrate content was determined as the method described by Cafado et al. (1975).

\section{Statistical analysis:}

All collected data were subjected to statistical analysis according to Sndecor and Cochran (1991) where the least significant difference was considered when even possible.

\section{Results and Discussion}

\section{Vegetative growth characteristics:-}

Data presented in Tables 1 and 2 show that using the highest rate of fertilizer i.e. $200 \mathrm{~kg} \mathrm{~N}+300 \mathrm{~kg}$ $\mathrm{K}_{2} \mathrm{O} /$ fed significantly reflected the highest values in all studied growth traits i.e., plant height, number of leaves and crown per plant, crown diameter, average leaf area as well as fresh and dry weight per plant during both seasons. Such increment in all studied growth parameters as a result of increasing the amounts of mineral fertilizers to $200 \mathrm{~kg} \mathrm{~N}+300 \mathrm{~kg}$ $\mathrm{K}_{2} \mathrm{O}$ may by attributed to the main role of macro nutrients $(\mathrm{N}$ and $\mathrm{K}$ ) on formation of protoplasmic material, cell division and cell elongation as well as increase the bio- chemicals reactions which affect the rate of plant growth. as found by, Abd El- Aziz (2007), Abo Sedera et al. (2009), and Mosalem (2010)

In Tables 1 and 2 obtained data show clearly that spaying strawberry plants with salicylic acid at $1 \mathrm{~g} /$ Liter and yeast extract at $100 \mathrm{ml} /$ Liter gave the highest values of all vegetative growth characters during both seasons. The increase in growth due to the application of the tested stimulants may be attributed to the role of such materials as antioxidants which contract the free radicals which affect the activity and viability of plant cells. Also it affects the physiological processes of plants and promotes plant growth.

Obtained results are in accordance with those reported by Saleh (2004), Abo Sedera et al. (2009), Shafshak et al. (2010) and Ahmed (2011)

Data recorded in Tables 1 and 2 show cleary that application of mineral fertilizers at the highest used levels $150 \mathrm{~kg} \mathrm{~N}+200 \mathrm{~kg} \mathrm{~K} 2 \mathrm{O}$ and $200 \mathrm{~kg} \mathrm{~N}+300 \mathrm{~kg}$ $\mathrm{K}_{2} \mathrm{O}$ combined with spraying the plants with salicylic acid at $1 \mathrm{~g} / \mathrm{L}$ or yeast extract at $100 \mathrm{~mL} / \mathrm{L}$ exhibited the highest values in all measured growth parameters during both seasons of study.

\section{2- Chemical constituents of plant foliage}

Data recorded in Table 3 indicate that the highest level of mineral ( $\mathrm{N}$ and $\mathrm{K}$ ) fertilizers $(200 \mathrm{~kg}$ $\mathrm{N}+300 \mathrm{~kg} \mathrm{~K} \mathrm{~K}_{2} \mathrm{O} / \mathrm{fed}$ ) recorded the highest values in all assayed chemical constituents except total nitrogen and total crud protein which recorded the highest values in case of moderate mineral fertilizer level $(150 \mathrm{~kg} \mathrm{~N}+200 \mathrm{~kg}$ fed) during both seasons. Such increments in N, P and K content as a result of increaseing fertilization level may be due to the increase of such nutrients in roots biosphere and consequently increases its uptake and accumulation of such macro nutrients in plant foliage. Also the increase in total carbohydrate contents might be attributed to the main role of used macro-nutrients (NPK) as constituents of photo synthetic pigment molecules and increase assimilation rate for precursors of carbohydrates in leaves.

Results show also that foliar application of salicylic acid at $1 \mathrm{~g}$ liter exhibited the highest values of $\mathrm{N}, \mathrm{P}, \mathrm{K}$, protein and carbohydrates in plant foliage compared with the control and other used growth stimulant. during two seasons. In this connection, promoting effect of growth stimulants on the concentration of macro- elements was connected with its positive effect on vegetative growth parameters (Tables, 1 and 2), Moreover, such increasing tendency of $\mathrm{N}, \mathrm{P}, \mathrm{K}$, protein and carbohydrates as a result of studied growth stimulants may be attributed to its main role on the enzymes which may control the active absorption of nutrients and water from the soil. Obtained results are in the same line with those reported by 
Mohamed (2008),Shafshak et al.(2010) and Jamail et al. (2013).

As for the effect of the interaction, the same data in Table 3 indicate that fertilizing strawberry plants with the highest used level of macro- nutrients ( $\mathrm{N}$ and $\mathrm{K}$ ) combined with spraying the plants with either salicylic acid at $1 \mathrm{~g} / \mathrm{L}$ or yeast extract at 100 $\mathrm{m} / \mathrm{L}$ exerted the highest values of phosphorus, potassium and total carbohydrates during both seasons of study. In addition, using the medium level of mineral fertilizer ( $150 \mathrm{~kg} \mathrm{~N}$ plus $200 \mathrm{~kg} \mathrm{~K}_{2} \mathrm{O} / \mathrm{fed}$ ) combined with foliar spray of salicylic acid at $\mathrm{g} / \mathrm{L}$ reflected the highest values of both total nitrogen and crud protein in the two seasons of study.

Abd El-All (2009) and Karlidag et al (2009) reported similar results.

\section{3- Fruit yield and its components:}

Data recorded in Tables 4 and 5 show that application of mineral fertilizers ( $\mathrm{N}$ and $\mathrm{K}$ ) at (200 $\mathrm{Kg} \mathrm{N}+300 \mathrm{Kg} \mathrm{K}_{2} \mathrm{O}$ fed) exhibited the highest values for total produced yield and its components. Such increments in total produced yield and its components were connected with the increase in vegetative growth rate Tables (1 and 2) and fruit physical parameters (Table 6) which in turn affect the total fruit yield. In this connection, El Shal $\boldsymbol{e t}$ al. (2003), Ulvi et al. (2009)and Mosalem (2010) on strawberry indicated that total fruit yield and its components were enhanced as a result of mineral fertilizers (NPK). Data in Tables 4 and 5 reveale that spraying plants with salicylic acid at $1 \mathrm{~g} /$ liter exhibited the highest values in all determined yield parameters compared with other studied spray treatments during both seasons. Such increments in total produced yield and its components were connected with the increase in vegetative growth parameters Tables (1 and 2). Obtained results are in parallel to those reported by Shafshak et al. (2010). Also, data in Tables 4 and 5 reveale also that using the highest rate of $(\mathrm{N}, \mathrm{K})$ fertilizers $(200 \mathrm{~kg} \mathrm{~N}+300$ $\mathrm{kg} \mathrm{K}_{2} \mathrm{O}$ ) and spraying the plants with salicylic acid (1g / liter) reflected the highest produced yield and its components compared during with the other tested treatments both seasons of study.

\section{4-Fruit quality:-}

Data in Table 6 show that application of mineral fertilizers $(\mathrm{N}, \mathrm{K})$ at $\left(200 \mathrm{~kg} \mathrm{~N}+300 \mathrm{~kg} \mathrm{~K}_{2} \mathrm{O} / \mathrm{fed}\right)$ exhibited the highest values for all measured fruit quality traits. Increasing the rate of $\mathrm{N}, \mathrm{K}$ fertilizer up to $\left(200 \mathrm{~kg} \mathrm{~N}+300 \mathrm{~kg} \mathrm{~K}_{2} \mathrm{O}\right)$. Such results may be attributed to such macro-nutrients are necessary to cells formation and division as well as increasing rates of photosynthetic assimilates and migration of it to storage organs (fruit) and in turn increase its parameters. In this regard, Abo-El Hamed et al. (2006) reported that application of nitrogen and potassium fertilizers increased physical fruit quality expressed as fruit length, diameter and size. However, Abd El- Aziz (2007) indicated that application of mineral fertilizer did not affect physical fruit quality. Obtained results are similar to those reported by Ghoneim et al. (2003), El- Sayed (2004), Abo El Hamd et al. (2006) and Abd ElAziz (2007) . In Table 6 data reveale also that spraying plants with salicylic acid at $1 \mathrm{~g} /$ Liter and yeast at $100 \mathrm{ml} /$ Liter significantly increased average fruit length, diameter, weight and fruit firmness compared with the control treatment. Such increment in fruit parameters due to salicylic acid treatment may be attributed to the role of salicylic acid on increasing the uptake of NPK (Table 6) and the absorption of water by roots which in turn increased fruit size. Similar observation were recorded by Saleh (2004), Babalar et al. (2007) and Shafshak et al. (2010) on strawberry. As for the interaction, data in Table 6 reveal that supplying the plant with mineral fertilizer at rate $(200 \mathrm{~kg} \mathrm{~N}+300 \mathrm{Kg}$ $\mathrm{K}_{2} \mathrm{O} /$ fed) combined with spraying the plants with salicylic acid at $1 /$ Liter reflected the highest values of all determined physical fruit quality characters (average fruit length, diameter, weight and fruit firmness) during both seasons.

Data recorded in Tables 7 and 8 indicate that fertilizing the plant with mineral fertilizer ( $\mathrm{N}$ and $\mathrm{K}$ ) at $100 \mathrm{~kg} \mathrm{~N}+100 \mathrm{~kg} \mathrm{~K} \mathrm{~K}_{2} \mathrm{O}, 150 \mathrm{Kg} \mathrm{N}+200 \mathrm{~kg} \mathrm{~K}_{2} \mathrm{O}$ or $200 \mathrm{~kg} \mathrm{~N}+300 \mathrm{~kg} \mathrm{~K} \mathrm{~K}_{2} \mathrm{O} /$ fed significantly affected TSS, V.C and total sugars content during the first season and TSS, total sugars and nitrate content during the second season. However it did not affect total acidity, anthocyanine and nitrate content during the first season and V.C, total acidity and anthocyanine pigment contents during the second season. In this respect, the highest level of mineral ( $\mathrm{N}$ and $\mathrm{K}$ ) fertilizers $\left(200 \mathrm{~kg} \mathrm{~N}+300 \mathrm{~kg} \mathrm{~K} \mathrm{~K}_{2} \mathrm{O} / \mathrm{fed}\right)$ recorded the highest values in all assayed chemical constituents during both seasons.

Spraying the plants with salicylic acid increased all assayed organic constituents (TSS, Vitamin C, acidity, total sugars and Anthocyanine content compared with yeast extract and control treatment (Table 7 and 8). Finally, using the highest rate of $\mathrm{N}$ and $\mathrm{K}(200 \mathrm{~kg} \mathrm{~N}+300 \mathrm{~kg} \mathrm{~K} 2 \mathrm{O} /$ fed) fertilizers and spraying the plants with salicylic acid $(1 \mathrm{~g} / \mathrm{Liter})$ increased all determined constituents (TSS, Vitamin $\mathrm{C}$, acidity, total sugars and anthocyanine) compared with the other interaction treatments. 
Table1. Effect of fertigation using N K mineral fertilizers and foliar spray with growth stimulants as well as their interaction on vegetative growth characteristics of strawberry plants cv. Florida during 2011/2012 season.

\begin{tabular}{|c|c|c|c|c|c|c|c|c|}
\hline \multicolumn{2}{|c|}{ Treatments } & \multicolumn{7}{|c|}{$2011 / 2012$} \\
\hline $\mathbf{N}, \mathbf{K}(\mathbf{k g} / \mathbf{f e d})$ & Spray & $\begin{array}{l}\text { Plant height } \\
\text { (cm) }\end{array}$ & $\begin{array}{c}\text { Fresh } \\
\text { weight }(g)\end{array}$ & $\begin{array}{c}\text { Dry } \\
\text { weight(g) }\end{array}$ & $\begin{array}{c}\begin{array}{c}\text { Number of } \\
\text { Leaves }\end{array} \\
\end{array}$ & $\begin{array}{c}\text { Number of } \\
\text { crowns }\end{array}$ & $\begin{array}{c}\text { Crown } \\
\text { diameter }(\mathbf{c m})\end{array}$ & Leaf $\operatorname{area}(\mathrm{cm} 2)$ \\
\hline $100 \mathrm{kgN}+100 \mathrm{~kg} \mathrm{~K} \mathrm{~K}_{2} \mathrm{O}$ & & 19.13 & 31.92 & 9.86 & 13.83 & 2.04 & 1.82 & 792.6 \\
\hline $150 \mathrm{kgN}+200 \mathrm{~kg} \mathrm{~K} \mathrm{O}$ & & 20.78 & 51.38 & 12.95 & 17.29 & 2.77 & 2.15 & 884.7 \\
\hline $200 \mathrm{kgN}+300 \mathrm{~kg} \mathrm{~K} \mathrm{~K}_{2} \mathrm{O}$ & & 20.94 & 62.93 & 15.77 & 18.05 & 3.02 & 2.39 & 984.6 \\
\hline LSD at $0.5 \%$ & & 1.07 & 15.22 & 3.20 & 2.85 & 0.61 & 0.06 & NS \\
\hline \multirow[b]{4}{*}{ LSD at $0.5 \%$} & Control & 18.21 & 37.22 & 10.26 & 14.63 & 2.09 & 1.94 & 736.7 \\
\hline & Salicylic acid (1g/l) & 21.73 & 55.53 & 14.44 & 17.81 & 3.08 & 2.41 & 989.6 \\
\hline & yeast extract $(100 \mathrm{ml} / \mathrm{l})$ & 20.90 & 53.50 & 13.88 & 16.74 & 2.65 & 2.02 & 935.6 \\
\hline & & 1.11 & 13.78 & 1.75 & 2.53 & 0.48 & 0.22 & 150.4 \\
\hline \multirow{4}{*}{$100 \mathrm{kgN}+100 \mathrm{~kg} \mathrm{~K} \mathrm{~K}_{2} \mathrm{O}$} & Control & 17.44 & 24.95 & 7.72 & 11.83 & 1.65 & 1.67 & 584.7 \\
\hline & Salicylic acid (1g/l) & 19.91 & 35.33 & 11.86 & 15.00 & 2.63 & 2.10 & 875.0 \\
\hline & yeast extract $(100 \mathrm{ml} / \mathrm{l})$ & 20.02 & 35.49 & 9.99 & 14.67 & 1.83 & 1.70 & 918.1 \\
\hline & Control & 18.39 & 36.97 & 8.80 & 16.78 & 2.00 & 1.95 & 793.9 \\
\hline \multirow[t]{3}{*}{$150 \mathrm{kgN}+200 \mathrm{~kg} \mathrm{~K} \mathrm{~K}_{2} \mathrm{O}$} & Salicylic acid (1g/l) & 22.44 & 60.33 & 14.58 & 17.89 & 3.13 & 2.40 & 914.8 \\
\hline & yeast extract $(100 \mathrm{ml} / \mathrm{l})$ & 21.50 & 56.84 & 15.48 & 17.22 & 3.19 & 2.10 & 945.2 \\
\hline & Control & 18.80 & 49.73 & 14.25 & 15.28 & 2.63 & 2.20 & 831.3 \\
\hline \multirow[t]{2}{*}{$200 \mathrm{kgN}+300 \mathrm{~kg} \mathrm{~K} \mathrm{~K}_{2} \mathrm{O}$} & Salicylic acid (1g/l) & 22.83 & 70.93 & 16.88 & 20.55 & 3.50 & 2.72 & 1179.0 \\
\hline & yeast extract $(100 \mathrm{ml} / \mathrm{l})$ & 21.18 & 68.15 & 16.18 & 18.33 & 2.94 & 2.27 & 943.5 \\
\hline LSD at $0.5 \%$ & & 1.9190 & 23.87 & $\mathbf{3 . 0 3}$ & 4.54 & 0.76 & 0.38 & 260.6 \\
\hline
\end{tabular}


Table2. Effect of fertigation using N K mineral fertilizers and foliar spray with growth stimulants as well as their interaction on vegetative growthcharacteristics of strawberry plants cv. Florida during 20012/2013 season.

\begin{tabular}{|c|c|c|c|c|c|c|c|c|}
\hline \multicolumn{2}{|c|}{ Treatments } & \multirow[b]{2}{*}{$\begin{array}{c}\text { Plant height } \\
\text { (cm) }\end{array}$} & \multirow[b]{2}{*}{$\begin{array}{c}\text { Fresh weight } \\
\text { (g) }\end{array}$} & \multirow[b]{2}{*}{$\begin{array}{l}\text { Dry weight } \\
(\mathrm{g})\end{array}$} & \multicolumn{2}{|c|}{$2012 / 2013$} & \multirow[b]{2}{*}{$\begin{array}{c}\text { Crown diameter } \\
(\mathrm{cm})\end{array}$} & \multirow[b]{2}{*}{$\begin{array}{l}\text { Leaf area } \\
\left(\mathrm{cm}^{2}\right)\end{array}$} \\
\hline $\mathbf{N}, \mathbf{K}(\mathbf{k g} / \mathbf{f e d})$ & Spray & & & & $\begin{array}{c}\text { Number of } \\
\text { Leaves }\end{array}$ & $\begin{array}{c}\text { Number of } \\
\text { crowns }\end{array}$ & & \\
\hline $100 \mathrm{kgN}+100 \mathrm{~kg} \mathrm{~K}_{2} \mathrm{O}$ & & 24.26 & 65.99 & 17.28 & 28.24 & 3.875 & 2.52 & 1374.2 \\
\hline $150 \mathrm{kgN}+200 \mathrm{~kg} \mathrm{~K} \mathrm{~K}_{2} \mathrm{O}$ & & 25.29 & 78.03 & 18.82 & 32.15 & 3.92 & 2.68 & 1462.4 \\
\hline $200 \mathrm{kgN}+300 \mathrm{~kg} \mathrm{~K} \mathrm{O}$ & & 25.57 & 82.24 & 20.17 & 32.45 & 3.89 & 2.87 & 1496.7 \\
\hline LSD at $0.5 \%$ & & 0.86 & 5.77 & 1.89 & 2.73 & NS & 0.24 & NS \\
\hline \multirow[b]{4}{*}{ LSD at $0.5 \%$} & Control & 24.46 & 65.53 & 16.60 & 25.90 & 3.25 & 2.48 & 1312.2 \\
\hline & $\begin{array}{l}\text { Salicylic acid } \\
\text { (1g/l) }\end{array}$ & 25.78 & 83.67 & 20.44 & 33.87 & 4.48 & 2.77 & 1559.3 \\
\hline & $\begin{array}{l}\text { yeast extract } \\
(100 \mathrm{ml} / \mathrm{l})\end{array}$ & 24.88 & 77.06 & 19.22 & 33.07 & 3.96 & 2.82 & 1461.8 \\
\hline & & 1.08 & 5.54 & 1.30 & 2.59 & 0.66 & 0.23 & 127.3 \\
\hline \multirow{4}{*}{$100 \mathrm{kgN}+100 \mathrm{~kg} \mathrm{~K} \mathrm{~K}_{2} \mathrm{O}$} & Control & 23.30 & 59.63 & 15.90 & 24.33 & 3.38 & 2.38 & 1261.8 \\
\hline & $\begin{array}{l}\text { Salicylic acid } \\
\text { (1g/l) }\end{array}$ & 25.05 & 70.09 & 18.45 & 31.28 & 4.50 & 2.56 & 1504.6 \\
\hline & $\begin{array}{l}\text { yeast extract } \\
(100 \mathrm{ml} / \mathrm{l})\end{array}$ & 24.42 & 68.27 & 17.48 & 29.10 & 3.75 & 2.63 & 1356.3 \\
\hline & Control & 25.10 & 67.18 & 16.20 & 26.67 & 3.25 & 2.38 & 1298.0 \\
\hline \multirow[t]{2}{*}{$150 \mathrm{kgN}+200 \mathrm{~kg} \mathrm{~K} \mathrm{~K}_{2} \mathrm{O}$} & $\begin{array}{l}\text { Salicylic acid } \\
\text { (1g/l) }\end{array}$ & 25.88 & 89.52 & 21.20 & 34.83 & 4.25 & 2.78 & 1585.9 \\
\hline & $\begin{array}{c}\text { yeast extract } \\
(100 \mathrm{ml} / \mathrm{l})\end{array}$ & 24.89 & 77.40 & 19.09 & 34.94 & 4.26 & 2.90 & 1503.4 \\
\hline \multirow{4}{*}{$200 \mathrm{kgN}+300 \mathrm{~kg} \mathrm{~K}_{2} \mathrm{O}$} & Control & 24.99 & 69.79 & 17.71 & 26.70 & 3.13 & 2.70 & 1376.8 \\
\hline & $\begin{array}{l}\text { Salicylic acid } \\
\text { (1g/l) }\end{array}$ & 26.41 & 91.41 & 21.68 & 35.50 & 4.68 & 3.13 & 1587.4 \\
\hline & $\begin{array}{l}\text { yeast extract } \\
(100 \mathrm{ml} / \mathrm{l})\end{array}$ & 25.32 & 85.51 & 21.13 & 35.16 & 3.88 & 2.79 & 1525.8 \\
\hline & & 1.87 & 13.18 & 2.25 & 6.16 & 1.14 & 0.40 & 220.5 \\
\hline
\end{tabular}


Table 3. Effect of fertigation using N,K mineral fertilizers and foliar spray with growth stimulants as well as their interaction on chemical constituents of plant foliage of strawberry plants cv. Florida during 2011/2012 and 2012/2013 seasons.

\begin{tabular}{|c|c|c|c|c|c|c|c|c|c|c|c|}
\hline \multicolumn{2}{|c|}{ Treatments } & \multicolumn{5}{|c|}{$2011 / 2012$} & \multicolumn{5}{|c|}{$2012 / 2013$} \\
\hline $\mathbf{N}, \mathbf{K}(\mathbf{k g} / \mathbf{f e d})$ & Spray & $\mathbf{N} \%$ & $\mathbf{P \%}$ & $\mathbf{K} \%$ & $\begin{array}{c}\text { Total crude } \\
\text { protein }\end{array}$ & $\begin{array}{c}\text { Carbohydrate } \\
\text { s } \\
\text { (g/ 100 g d.w.) }\end{array}$ & $\mathbf{N \%}$ & $\mathbf{P \%}$ & $\mathbf{K} \%$ & $\begin{array}{c}\text { Total crude } \\
\text { protein }\end{array}$ & $\begin{array}{c}\text { Carbohydrate } \\
\text { s } \\
\text { (g/ } 100 \text { g d.w.) }\end{array}$ \\
\hline $100 \mathrm{kgN}+100 \mathrm{~kg} \mathrm{~K} \mathrm{~K}_{2} \mathrm{O}$ & & 1.58 & 0.45 & 1.45 & 9.84 & 14.93 & 1.58 & 0.45 & 1.44 & 9.89 & 14.52 \\
\hline $150 \mathrm{kgN}+200 \mathrm{~kg} \mathrm{~K}_{2} \mathrm{O}$ & & 1.81 & 0.47 & 1.49 & 11.34 & 15.4 & 1.75 & 0.48 & 1.48 & 11.03 & 14.52 \\
\hline $200 \mathrm{kgN}+300 \mathrm{~kg} \mathrm{~K}_{2} \mathrm{O}$ & & 1.69 & 0.48 & 1.53 & 10.55 & 15.64 & 1.68 & 0.49 & 1.52 & 10.48 & 14.62 \\
\hline LSD at $0.5 \%$ & & N S & $\mathbf{0 . 0 3}$ & $\mathbf{0 . 0 3}$ & NS & N S & NS & 0.02 & 0.04 & NS & N S \\
\hline \multirow[b]{4}{*}{ LSD at $0.5 \%$} & Control & 1.64 & 0.45 & 1.44 & 10.24 & 14.49 & 1.59 & 0.45 & 1.43 & 9.93 & 14.33 \\
\hline & $\begin{array}{l}\text { Salicylic acid } \\
(1 \mathrm{~g} / \mathrm{l})\end{array}$ & 1.73 & 0.48 & 1.53 & 10.84 & 15.92 & 1.73 & 0.48 & 1.52 & 10.79 & 14.79 \\
\hline & $\begin{array}{c}\text { yeast extract } \\
(100 \mathrm{ml} / \mathrm{l})\end{array}$ & 1.71 & 0.48 & 1.5 & 10.66 & 15.56 & 1.71 & 0.48 & 1.49 & 10.68 & 14.64 \\
\hline & & NS & $\mathbf{0 . 0 2}$ & $\mathbf{0 . 0 3}$ & NS & 0.96 & NS & 0.02 & 0.03 & NS & N S \\
\hline \multirow{4}{*}{$100 \mathrm{kgN}+100 \mathrm{~kg} \mathrm{~K} \mathrm{~K}_{2} \mathrm{O}$} & Control & 1.66 & 0.4 & 1.42 & 10.36 & 14.71 & 1.46 & 0.41 & 1.42 & 9.14 & 14.90 \\
\hline & $\begin{array}{c}\text { Salicylic acid } \\
(1 \mathrm{~g} / \mathrm{l})\end{array}$ & 1.57 & 0.48 & 1.48 & 9.78 & 15.13 & 1.80 & 0.48 & 1.47 & 11.27 & 14.54 \\
\hline & $\begin{array}{c}\text { yeast extract } \\
(100 \mathrm{ml} / \mathrm{l})\end{array}$ & 1.5 & 0.47 & 1.45 & 9.39 & 14.96 & 1.48 & 0.47 & 1.43 & 9.26 & 14.12 \\
\hline & Control & 1.8 & 0.47 & 1.44 & 11.26 & 14.37 & 1.71 & 0.48 & 1.43 & 10.67 & 14.47 \\
\hline \multirow[t]{2}{*}{$150 \mathrm{kgN}+200 \mathrm{~kg} \mathrm{~K}_{2} \mathrm{O}$} & $\begin{array}{c}\text { Salicylic acid } \\
(1 \mathrm{~g} / \mathrm{l})\end{array}$ & 1.82 & 0.47 & 1.53 & 11.39 & 15.94 & 1.76 & 0.48 & 1.51 & 11.02 & 14.56 \\
\hline & $\begin{array}{c}\text { yeast extract } \\
(100 \mathrm{ml} / \mathrm{l})\end{array}$ & 1.82 & 0.48 & 1.51 & 11.37 & 15.88 & 1.82 & 0.48 & 1.51 & 11.39 & 14.86 \\
\hline \multirow{3}{*}{$200 \mathrm{kgN}+300 \mathrm{~kg} \mathrm{~K}_{2} \mathrm{O}$} & Control & 1.45 & 0.47 & 1.47 & 9.09 & 14.38 & 1.59 & 0.47 & 1.46 & 9.97 & 13.61 \\
\hline & $\begin{array}{c}\text { Salicylic acid } \\
(1 \mathrm{~g} / \mathrm{l})\end{array}$ & 1.81 & 0.48 & 1.58 & 11.34 & 16.68 & 1.61 & 0.48 & 1.57 & 10.08 & 15.27 \\
\hline & $\begin{array}{c}\text { yeast extract } \\
(100 \mathrm{ml} / \mathrm{l})\end{array}$ & 1.80 & 0.48 & 1.55 & 11.22 & 15.85 & 1.82 & 0.48 & 1.53 & 11.39 & 14.98 \\
\hline LSD at $0.5 \%$ & & NS & $\mathbf{0 . 0 3}$ & 0.05 & NS & 1.67 & NS & 0.04 & 0.06 & NS & 1.06 \\
\hline
\end{tabular}


Table 4. Effect of fertigation using N K mineral fertilizers and foliar spray with growth stimulants as well as their interaction on total fruit yield and its components of strawberry plants of cv. Florida during 2011/2012 season.

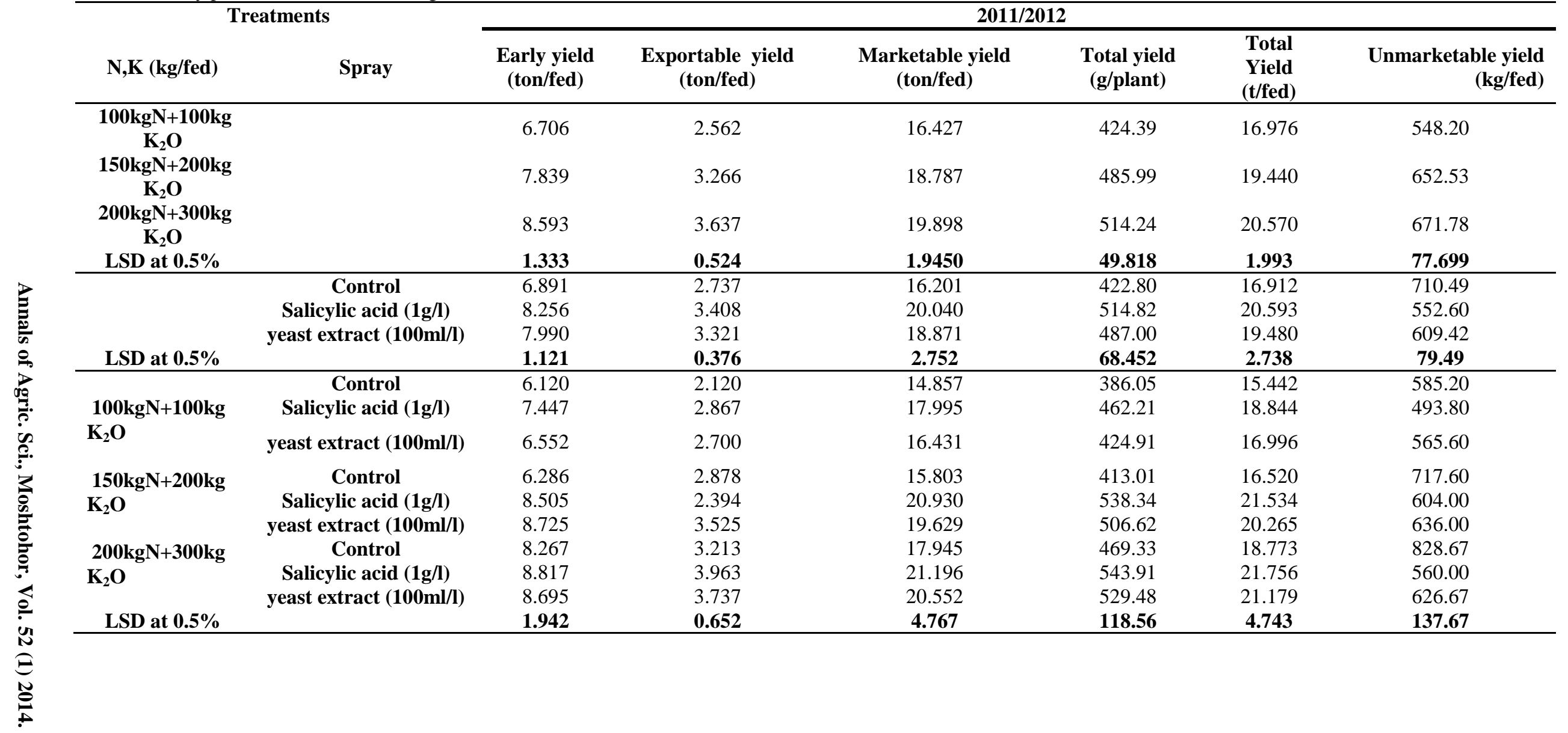


Table 5. Effect of fertigation using N K mineral fertilizers and foliar spray with growth stimulants as well as their interaction on total fruit yield and its components of strawberry plants cv. Florida during 2012/2013 season.

\begin{tabular}{|c|c|c|c|c|c|c|c|}
\hline \multicolumn{2}{|c|}{ Treatments } & \multicolumn{6}{|c|}{$2012 / 2013$} \\
\hline N,K (kg/fed) & Spray & $\begin{array}{c}\text { Early } \\
\text { yield } \\
\text { (ton/fed) }\end{array}$ & $\begin{array}{c}\text { Exportable yield } \\
(\text { ton/fed })\end{array}$ & $\begin{array}{l}\text { Marketable yield } \\
\quad \text { (ton/fed) }\end{array}$ & $\begin{array}{l}\text { Total yield } \\
\text { (g/plant) }\end{array}$ & $\begin{array}{l}\text { Total } \\
\text { Yield } \\
(\mathrm{t} / \text { fed }) \\
\end{array}$ & $\begin{array}{r}\text { Unmarketable } \\
\text { yield(kg/fed) }\end{array}$ \\
\hline $100 \mathrm{kgN}+100 \mathrm{~kg}$ & & & & & 367.15 & 14.686 & \\
\hline $\mathrm{K}_{2} \mathrm{O}$ & & 6.730 & 2.618 & 14.474 & & & 211.37 \\
\hline $150 \mathrm{kgN}+200 \mathrm{~kg}$ & & & & & 468.48 & 18.739 & \\
\hline $\mathrm{K}_{2} \mathrm{O}$ & & 7.245 & 2.872 & 18.294 & & & 444.70 \\
\hline $200 \mathrm{kgN}+300 \mathrm{~kg}$ & & & & & 481.34 & 19.254 & \\
\hline $\mathrm{K}_{2} \mathrm{O}$ & & 7.847 & 3.176 & 18.709 & & & 545.72 \\
\hline LSD at $0.5 \%$ & & 0.9178 & 0.492 & 1.118 & 25.937 & 1.038 & 236.47 \\
\hline & Control & 6.290 & 2.476 & 15.797 & 407.65 & 16.306 & 509.23 \\
\hline & Salicylic acid (1g/l) & 7.992 & 3.195 & 18.119 & 460.83 & 18.433 & 313.05 \\
\hline & yeast extract $(100 \mathrm{ml} / \mathrm{l})$ & 7.540 & 2.995 & 17.560 & 448.49 & 17.940 & 379.51 \\
\hline LSD at $0.5 \%$ & & 1.055 & 0.380 & 1.547 & 38.244 & 1.530 & 123.02 \\
\hline \multirow{4}{*}{$\begin{array}{c}100 \mathrm{kgN}+100 \mathrm{~kg} \\
\mathrm{~K}_{2} \mathrm{O}\end{array}$} & Control & 6.232 & 2.145 & 13.688 & 349.58 & 13.983 & 296.47 \\
\hline & Salicylic acid (1 $\sigma / 1)$ & & & & 379.52 & 15.181 & \\
\hline & Salicylic acid (1g/l) & 6.734 & 2.931 & 14.991 & & & 187.35 \\
\hline & yeast extract $(100 \mathrm{ml} / \mathrm{l})$ & 7.225 & 2.777 & 14.743 & 372.34 & 14.894 & 150.29 \\
\hline \multirow{3}{*}{$\begin{array}{c}150 \mathrm{kgN}+200 \mathrm{~kg} \\
\mathrm{~K}_{2} \mathrm{O}\end{array}$} & Control & 6.146 & 2.561 & 16.949 & 438.93 & 17.557 & 607.35 \\
\hline & & & & & 486.85 & 19.474 & \\
\hline & Salicylic acid (1g/l) & 7.986 & 2.986 & 19.163 & & & 310.88 \\
\hline \multirow{5}{*}{$\begin{array}{c}200 \mathrm{kgN}+300 \mathrm{~kg} \\
\mathrm{~K}_{2} \mathrm{O}\end{array}$} & yeast extract $(100 \mathrm{ml} / \mathrm{l})$ & 7.602 & 3.070 & 18.769 & 479.65 & 19.186 & 415.88 \\
\hline & Control & 6.493 & 2.721 & 16.754 & 434.43 & 17.377 & 623.88 \\
\hline & & & & & 516.11 & 20.644 & \\
\hline & Salicylic acid (1g/l) & 9.255 & 3.668 & 20.203 & & & 440.92 \\
\hline & yeast extract $(100 \mathrm{ml} / \mathrm{l})$ & 7.794 & 3.138 & 19.169 & 493.48 & 19.739 & 572.35 \\
\hline LSD at $0.5 \%$ & & 1.827 & 0.658 & 2.679 & 66.241 & 2.650 & 213.08 \\
\hline
\end{tabular}


Table 6. Effect of fertigation using N K mineral fertilizers and foliar spray with growth stimulants as well as their interaction on physical fruit quality of strawberry plants cv. Florida during 2011/2012 and 2012/2013 seasons.

\begin{tabular}{|c|c|c|c|c|c|c|c|c|c|}
\hline \multicolumn{2}{|c|}{ Treatments } & \multicolumn{4}{|c|}{ 2011/2012 } & \multicolumn{4}{|c|}{$2012 / 2013$} \\
\hline $\mathbf{N}, \mathbf{K}(\mathbf{k g} / \mathbf{f e d})$ & Spray & $\begin{array}{c}\text { Fruit weight } \\
\text { (g) }\end{array}$ & $\begin{array}{l}\text { Fruit length } \\
\qquad(\mathrm{cm})\end{array}$ & $\begin{array}{l}\text { Fruit diameter } \\
\text { (cm) }\end{array}$ & $\begin{array}{l}\text { Fruit firmness } \\
\quad(\mathrm{g} / \mathrm{cm} 2)\end{array}$ & $\begin{array}{c}\text { Fruit } \\
\text { weigh } \\
\mathbf{t}(\mathrm{g})\end{array}$ & $\begin{array}{c}\text { Fruit } \\
\text { lengt } \\
\text { h } \\
(\mathrm{cm}) \\
\end{array}$ & $\begin{array}{c}\text { Fruit } \\
\text { diamete } \\
\text { r (cm) }\end{array}$ & $\begin{array}{c}\text { Fruit } \\
\text { firmnes } \\
\text { s } \\
(\mathrm{g} / \mathrm{cm} 2) \\
\end{array}$ \\
\hline $\begin{array}{c}100 \mathrm{kgN}+100 \mathrm{k} \\
\mathrm{g} \mathrm{K}_{2} \mathrm{O}\end{array}$ & & 15.83 & 4.14 & 2.98 & 142.38 & 19.88 & 4.19 & 3.12 & 98.78 \\
\hline $\begin{array}{c}150 \mathrm{kgN}+200 \mathrm{k} \\
\mathrm{g} \mathrm{K}_{2} \mathrm{O}\end{array}$ & & 17.56 & 4.29 & 3.19 & 155.63 & 21.03 & 4.28 & 3.32 & 100.25 \\
\hline $\begin{array}{c}200 \mathrm{kgN}+300 \mathrm{k} \\
\mathrm{g} \mathrm{K}_{2} \mathrm{O}\end{array}$ & & 17.85 & 4.33 & 3.27 & 162.01 & 21.04 & 4.31 & 3.26 & 107.59 \\
\hline LSD at $0.5 \%$ & & 1.31 & 0.19 & 0.15 & 11.31 & 0.96 & 0.08 & 0.12 & 1.49 \\
\hline & Control & 14.84 & 4.01 & 2.99 & 147.70 & 19.16 & 4.19 & 3.12 & 100.29 \\
\hline & Salicylic acid (1g/l) & 18.80 & 4.42 & 3.24 & 157.99 & 22.07 & 4.33 & 3.32 & 105.43 \\
\hline & $\begin{array}{c}\text { yeast extract } \\
(100 \mathrm{ml} / \mathrm{l})\end{array}$ & 17.59 & 4.33 & 3.20 & 154.33 & 20.71 & 4.26 & 3.26 & 100.90 \\
\hline LSD at $0.5 \%$ & & 0.89 & 0.12 & 0.12 & 7.21 & 0.85 & 0.09 & 0.12 & 3.39 \\
\hline & Control & 13.40 & 3.99 & 2.89 & 130.00 & 18.19 & 4.11 & 3.01 & 97.55 \\
\hline LOK & SA 1g/l & 17.25 & 3.21 & 3.04 & 147.50 & 21.31 & 4.32 & 3.22 & 102.50 \\
\hline $\mathrm{g} \mathrm{N}_{2} \mathrm{O}$ & yeast $100 \mathrm{ml} / \mathrm{l}$ & 16.84 & 3.21 & 3.01 & 149.64 & 20.85 & 4.15 & 3.09 & 96.28 \\
\hline & Control & 15.67 & 4.04 & 3.07 & 155.84 & 19.99 & 4.22 & 3.28 & 100.33 \\
\hline $150 \mathrm{kgN}+200 \mathrm{k}$ & SA 1g/l & 19.28 & 4.51 & 3.29 & 158.97 & 22.23 & 4.30 & 3.35 & 100.67 \\
\hline & yeast $100 \mathrm{ml} / \mathrm{l}$ & 17.73 & 4.32 & 3.21 & 152.08 & 20.85 & 4.32 & 3.37 & 99.75 \\
\hline & Control & 15.47 & 4.00 & 3.04 & 157.25 & 19.30 & 4.24 & 3.08 & 102.97 \\
\hline 200KgN+500K & SA 1g/l & 19.88 & 4.54 & 3.40 & 167.50 & 22.66 & 4.37 & 3.39 & 113.13 \\
\hline $\mathrm{g} \mathrm{K}_{2} \mathbf{U}$ & yeast $100 \mathrm{ml} / \mathrm{l}$ & 18.20 & 4.46 & 3.37 & 161.28 & 21.14 & 4.33 & 3.32 & 106.67 \\
\hline LSD at $0.5 \%$ & & 1.54 & 0.20 & 0.21 & 12.49 & 1.48 & 0.17 & 0.21 & 5.89 \\
\hline
\end{tabular}


Table7. Effect of fertigation using N K mineral fertilizers and foliar spray with growth stimulants as well as their interaction on on chemical constituents in fruits of strawberry plants cv. Florida during 2011/2012 season.

\begin{tabular}{|c|c|c|c|c|c|c|c|}
\hline \multicolumn{2}{|c|}{ Treatments } & \multicolumn{6}{|c|}{ 2011/2012 } \\
\hline N,K (kg/fed) & spray & TSS\% & $\begin{array}{c}\text { Vit.C } \\
\text { (mg/100g f.w) }\end{array}$ & Acidty (mg/100g f.w) & $\begin{array}{c}\text { Total } \\
\text { sugars \% }\end{array}$ & (mg/100g f.w) & Nitrate (ppm) \\
\hline $100 \mathrm{kgN}+100 \mathrm{~kg} \quad \mathrm{~K}_{2} \mathrm{O}$ & & 10.35 & 42.26 & 1.655 & 6.19 & 81.54 & 155.56 \\
\hline $150 \mathrm{kgN}+200 \mathrm{~kg} \mathrm{~K}_{2} \mathrm{O}$ & & 10.54 & 43.33 & 1.69 & 6.28 & 83.51 & 198.89 \\
\hline $200 \mathrm{kgN}+300 \mathrm{~kg} \mathrm{~K}_{2} \mathrm{O}$ & & 10.73 & 46.75 & 1.72 & 6.62 & 87.57 & 286.67 \\
\hline LSD at $0.5 \%$ & & 0.17 & 0.94 & NS & $\mathbf{0 . 3 0}$ & NS & NS \\
\hline \multirow[b]{4}{*}{ LSD at $0.5 \%$} & control & 10.32 & 42.28 & 1.62 & 6.16 & 79.18 & 247.78 \\
\hline & Salicylic acid (1g/l) & 10.73 & 45.07 & 1.82 & 6.18 & 88.13 & 208.33 \\
\hline & yeast extract $(100 \mathrm{ml} / \mathrm{l})$ & 10.57 & 44.99 & 1.62 & 6.75 & 85.30 & 185.00 \\
\hline & & $\mathbf{0 . 3 7}$ & 1.12 & 0.079 & 0.41 & 6.53 & NS \\
\hline \multirow{4}{*}{$100 \mathrm{kgN}+100 \mathrm{~kg} \quad \mathrm{~K}_{2} \mathrm{O}$} & control & 10.07 & 41.33 & 1.66 & 5.61 & 75.62 & 228.33 \\
\hline & Salicylic acid (1g/l) & 10.47 & 42.47 & 1.70 & 6.40 & 86.15 & 116.67 \\
\hline & yeast extract $(100 \mathrm{ml} / \mathrm{l})$ & 10.51 & 42.99 & 1.60 & 6.57 & 82.84 & 121.67 \\
\hline & control & 10.34 & 41.50 & 1.59 & 6.26 & 80.80 & 186.67 \\
\hline \multirow[t]{3}{*}{$150 \mathrm{kgN}+200 \mathrm{~kg} \mathrm{~K}_{2} \mathrm{O}$} & Salicylic acid (1g/l) & 10.76 & 44.50 & 1.87 & 5.83 & 87.43 & 235.00 \\
\hline & yeast extract $(100 \mathrm{ml} / \mathrm{l})$ & 10.53 & 44.00 & 1.60 & 6.75 & 82.30 & 175.00 \\
\hline & control & 10.56 & 43.99 & 1.60 & 6.62 & 81.14 & 328.33 \\
\hline \multirow[t]{2}{*}{$200 \mathrm{kgN}+300 \mathrm{~kg} \quad \mathrm{~K}_{2} \mathrm{O}$} & Salicylic acid (1g/l) & 10.96 & 48.25 & 1.89 & 6.29 & 90.82 & 273.33 \\
\hline & yeast extract $(100 \mathrm{ml} / \mathrm{l})$ & 10.67 & 48.00 & 1.67 & 6.94 & 90.77 & 258.33 \\
\hline LSD at $0.5 \%$ & & 0.64 & 1.93 & 0.14 & 0.71 & 11.31 & 161.32 \\
\hline
\end{tabular}


Table 8. Effect of fertigation using N K mineral fertilizers and foliar spray with growth stimulants as well as their interaction on on chemical constituents in fruits of strawberry plants cv. Florida during 2012/2013 season.

\begin{tabular}{|c|c|c|c|c|c|c|c|}
\hline \multicolumn{2}{|c|}{ Treatments } & \multicolumn{6}{|c|}{$2012 / 2013$} \\
\hline $\mathbf{N}, \mathbf{K}(\mathrm{kg} / \mathrm{fed})$ & spray & TSS \% & $\begin{array}{c}\text { Vit.C } \\
\text { (mg/100g f.w) }\end{array}$ & Acidty (mg/100g f.w) & $\begin{array}{c}\text { Total } \\
\text { sugars\% }\end{array}$ & $(\mathrm{mg} / 100 \mathrm{~g}$ f.w) & Nitrate (ppm) \\
\hline $100 \mathrm{kgN}+100 \mathrm{~kg} \mathrm{~K}_{2} \mathrm{O}$ & & 8.98 & 51.44 & 1.44 & 6.08 & 82.03 & 131.67 \\
\hline $150 \mathrm{kgN}+200 \mathrm{~kg} \mathrm{~K} \mathrm{~K}_{2} \mathrm{O}$ & & 9.34 & 51.67 & 1.53 & 6.17 & 86.00 & 238.89 \\
\hline $200 \mathrm{kgN}+300 \mathrm{~kg} \mathrm{~K}_{2} \mathrm{O}$ & & 9.74 & 53.22 & 1.56 & 6.48 & 87.31 & 267.78 \\
\hline LSD at $0.5 \%$ & & 0.69 & NS & NS & 0.38 & NS & 97.737 \\
\hline \multirow[b]{4}{*}{ LSD at $0.5 \%$} & control & 8.80 & 50.00 & 1.48 & 5.82 & 80.13 & 253.89 \\
\hline & Salicylic acid (1g/l) & 9.63 & 53.78 & 1.61 & 6.19 & 88.79 & 211.11 \\
\hline & yeast extract $(100 \mathrm{ml} / \mathrm{l})$ & 9.62 & 52.56 & 1.44 & 6.72 & 86.42 & 173.33 \\
\hline & & 0.40 & 1.97 & NS & 0.85 & 7.43 & NS \\
\hline \multirow{4}{*}{$100 \mathrm{kgN}+100 \mathrm{~kg} \quad \mathrm{~K}_{2} \mathrm{O}$} & control & 8.54 & 48.33 & 1.37 & 5.66 & 75.48 & 203.33 \\
\hline & Salicylic acid (1g/l) & 9.18 & 53.33 & 1.50 & 6.30 & 86.10 & 135.00 \\
\hline & yeast extract $(100 \mathrm{ml} / \mathrm{l})$ & 9.20 & 52.66 & 1.47 & 6.28 & 84.52 & 56.67 \\
\hline & control & 8.89 & 51.33 & 1.57 & 5.75 & 82.13 & 273.33 \\
\hline \multirow[t]{3}{*}{$150 \mathrm{kgN}+200 \mathrm{~kg} \mathrm{~K}_{2} \mathrm{O}$} & Salicylic acid (1g/l) & 9.45 & 53.00 & 1.57 & 6.05 & 88.64 & 213.33 \\
\hline & yeast extract $(100 \mathrm{ml} / \mathrm{l})$ & 9.69 & 50.67 & 1.47 & 6.72 & 87.24 & 230.00 \\
\hline & Control & 8.98 & 50.34 & 1.50 & 6.04 & 82.77 & 285.00 \\
\hline \multirow[t]{2}{*}{$200 \mathrm{kgN}+300 \mathrm{~kg} \mathrm{~K} \mathrm{~K}_{2} \mathrm{O}$} & Salicylic acid (1g/l) & 10.26 & 55.00 & 1.77 & 6.22 & 91.64 & 285.00 \\
\hline & yeast extract $(100 \mathrm{ml} / \mathrm{l})$ & 9.97 & 54.34 & 1.40 & 7.16 & 87.52 & 233.33 \\
\hline LSD at $0.5 \%$ & & 0.70 & 3.42 & 0.37 & 1.48 & 12.87 & 183.89 \\
\hline
\end{tabular}




\section{References}

A. O.A. C. (1990). Official and tentative methods of analysis. Association of Official Analytical Chemists. Washington, D.C,U.S.A.

Abd El-All, M. M. (2009).Improvement of tomato productivity by using certain natural materials. Ph.D. Thesis. Fac. of Agric., Benha univ.

Abd El-Aziz, M.G. (2007). Studies on fruiting regulation of some strawberry cultivars grown under new reclaimed soils conditions. Ph.D. Thesis, Fac. Agric., Ain Shams Univ., Egypt.

Abo-El-Hamd, A. S. A., A. A. Abdou, S. A. A. Mansour and A. A. A. El-Sayed. (2006). Effect of some biofertilizers on the yield and fruit quality of strawberry. Ann .of Agric. Sci., Moshtohor, 44(1): 251-264.

Abo Sedera, F. A., Nadia S. Shafsha, S. M. Eid and M. H. M. Mohamed. (2009): Improving productivity and quality of strawberry via organic fertilization and application of some natural growth stimulants $3^{\text {rd }}$ IRT international scientific Conference Intergrated Relational Tourism. territories and developmet in the Mediterranean area, Helwan Univ, Egypt, 24 $27^{\text {th }}$ October 2009 .

Ahmed, W.M.S. (2011). Some factors affecting runner formation and transplants production in strawberry nursery. M.Sc. Thesis, Fac. Agric., Ain Shams Univ., 52pp .

Ali. T. G. A. (2010). Physiological studies on growth, seeds yield and its quality of common bean. Ph. D Thesis. Fac. of Agric., Benha univ

Babalar, M., M. Asghari, A. Talaei and A. Khosroshahi .(2007). Effect of pre and post harvest salicylic acid treatment on ethylene production, fungal decay and overall quality of Selva strawberry fruit. Food chemistry J., 105:449-453.

Brown, J. and O. Lilliland. (1946). Rapid determination of potassium and sodium in plant material and soil extracts by flame photometric. Proc. Amer. Soc. Hort. Sci, 48: 341- 346.

Cafado, D. A.,M. Haroon, L. E. Sharderand and V. L. Youn.(1975). Rapid colorimetric determination of nitrate in plant tissues by nitrification of salicylic acid comm. Soil and plant Anal., 6:71-80.

El-Sayed, A. A. A. (2004). Effect of some nutrients on growth and yield of strawberry. M.Sc. Thesis. Fac. Of Agric., Al- Azhar Univ., Egypt.

El-Shal, M.A., S.M.El-Araby, I.M.Ghoneim and H. Anter. (2003). Effects of biofertilization under varying NPK levels on growth, yield and fruit quality of strawberry plants. J. Agric. \& Env. Sci., Alex. Univ., Egypt.2:106-129

Ghoneim, I.M., S.M. El-Araby, A.I. Shehata and R.A. Mohamed. (2003). Effects of nitrogen, organic manure and biofertilizer application on strawberry plants.II.yield and fruit quality. J. Agric. \& Env. Sci., Alex. Univ., Egypt. 2:63-87.

Jamali, B. Eshghi, S and Taffazoli, E. (2013). Vegetative growth, yield, fruit quality and fruit and leaf composition of strawberry cv. 'pajaro' as influenced by salicylic acid and nickel sprays. Journal of Plant Nutrition . 36: 7, 1043-1055.

James, C. S. (1995). Analytical chemistry of foods Blokie Academic, proffessional, London.

Kaponski, K. and Z. Kawecki. (1994). Nitrogen fertilization and growth and cropping of strawberries in the conditions of zulawy. 11. plant morphology and leaf chemical composition. Acta Academia Agric. 58.125-134. (C.F. Hort. Abstr. 66(6): 4890, 1996).

Karlidag, H. Yildirim, E. and Turan, M.(2009) Salicylic acid ameliorates the adverse effect of salt stress on strawberry. Scientia Agricola66: 2, 180-187.

Koch, F. C. and T. L. McMeekin .(1924) A new direct nasalization micro keldahl method and ammonium. J. Amer. Soc. Chem.., 46: 521.

Moasalem, S. M. R. (2010) Physiological studies on growth, yield and quality of some strawberry cultivars M.Sc. Thesis, Fac. of Agric.Moshtohor, Benha Uniiv.

Mohamed, M. H. M. (2008). Effect of some agricultural treatments on growth and productivity of strawberry M.Sc Thesis. Fac, of Agric., Benha univ.

Nelson, N. (1974). A photometric adaptation of the somogyi methods for determination of glucose. J. Biology. Chem. 195: 19-23.

Pregl, E. (1945). Quantitative organic micro analysis 4th ed. J. Chundrill, London.

Saleh,E. H. A . (2004). Studies on strawberry nutriton in sandy soil under drip irrigation system. M.Sc. Thesis, Fac. of Agric.Moshtohor, Benha Uniiv.

Shafshak, Nadia, S., S.M. Eid, F.A. Abo-Sedera and M.H.M. Mohamed (2010). Effect of nitrogen fertilization sources and foliar application of garlic extract, plant gured or salicylic acid on strawberry productivity and storability. The Fifth International Conference for Development and Environment in the Arab world. March 21-23, 2010. Assiut, Egypt. 357375.

Snedecor, G. W. and W.G. Cocharn. (1991). Statistical methods. $8^{\text {th }}$ E.d., lowa state univ. press, lowa. USA.

Trough, E. and Meyer. (1939) Improvement in denies calorimetric method for phosphorus and arsenic. Indian English Chemistry Analysis edition. 1:136- 139.

Ulvi M, Priit. P., T. Thutare, K. Karp and Strast El - Vool. (2009). Effect of phosphite fertilization on growth, yield and fruit composition of strawberries. Scientia Hort. 199: 264-269. 
إستجابة الفراولة لمعاملات حض السلسليك ومستخلص الخميرة تحت تراكيب مختلفة من

\section{النيتروجين والبوتاسيوم}

*تتحي أبو النصر أبو سديرة ؛ "طفى عبد الفتاح بدر ؛ *"أمانى عطية عبد اللطيف ؛ "*وسيد منصور رزق .

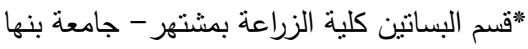
*ق"قسم بحوث البطاطس والخضر خضرية النكاثر -معهز بحوث البساتين -مركز البحوث الزراعية.$$
\text { الملخص العببي }
$$

إجريت هذه الدراسة خلال موسمي 2012/2011و 2013/2012 في مزرعة خاصه بقرية الدير مركز طوخ بمحافظة القليوبية لبحث إستجابة

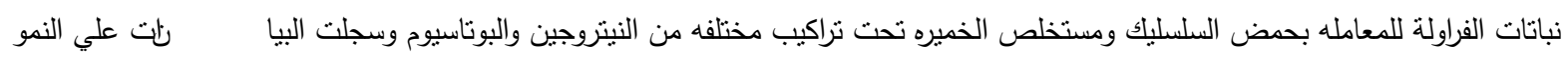
الخضري والمكونات الكييماوية والمحصول ومكوناتة .

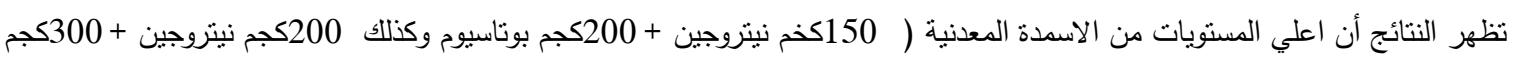

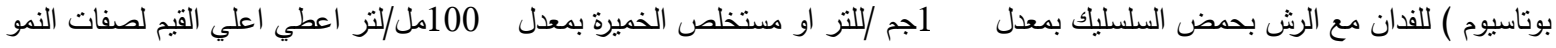

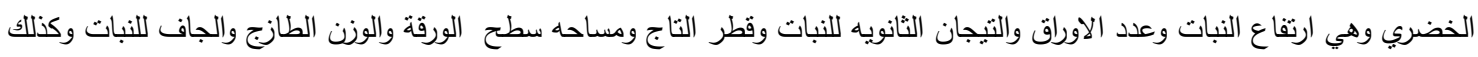

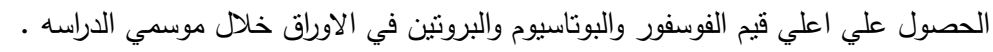

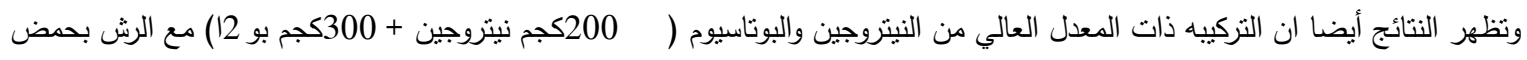

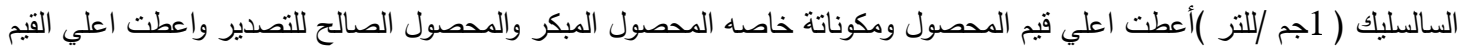

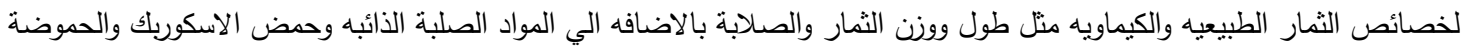

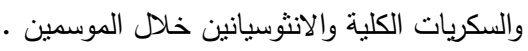
توصي الدراسة انة يفضل إضافه التزكيبه السماديه المعدنيه المكونه من 200كجم نيتروجين + 300كجم بوتاسيوم ورش النباتات بمعدل 1جم/للتر حمض السالسليك للحصول علي افضل نمو خضري ومحصول مبكر وكلي وصالح للتصدير وتحسين الخصائص الطبيعيه والكيماويه لثمار الفراوله في مزارع التصدير تحت ظروف محافظه القليوبيه .
} 